Marketing and Branding Research

WWW.CIKD.CA

\title{
Online Shopping Tendency and Customer Trust in Nigerian Service Sector
}

\author{
Idongesit Eshiett
}

Department of Marketing, Akwa Ibom State University, Oruk Anam, Nigeria

\begin{tabular}{|c|c|}
\hline & ABSTRACT \\
\hline $\begin{array}{l}\text { Keywords: } \\
\text { Customer Trust, Conventional } \\
\text { Marketing, Customer } \\
\text { Retention, Online Shopping, } \\
\text { Risk Factor }\end{array}$ & $\begin{array}{l}\text { Conventional shopping affords the customer the convenience of not losing their monies to } \\
\text { hackers and scammers and carrying out a transaction in a familiar shop environment, } \\
\text { irrespective of the shop location. The unprecedented development in telecommunication/ } \\
\text { Information Communications Technology (ICT) has made direct purchase and sale of goods } \\
\text { and services possible worldwide using the Internet, an online shopping website in Nigeria. For }\end{array}$ \\
\hline $\begin{array}{l}\text { Received } \\
24 \text { December } 2020 \\
\text { Received in revised form } \\
\text { 08 January } 2021 \\
\text { Accepted } \\
\text { 09 January } 2021\end{array}$ & $\begin{array}{l}\text { Jumia.com.ng and konga.com. The essence of trust in this platform becomes inevitable, based } \\
\text { on the virtual nature of all transactions. This study aims to examine the effect of customer trust } \\
\text { and purchase decisions on online shopping in Nigeria. The study clarifies that internet hopping } \\
\text { could flourish easily where there is less risk factor, proof of effective service quality delivery, } \\
\text { and unbridled evidence of trust in the service providers' ability to deliver. The descriptive } \\
\text { methodology was adopted for the study, and } 277 \text { questionnaires were administered to } \\
\text { respondents. mainly online customers of jumia.com.ng. Correlation analysis was used to }\end{array}$ \\
\hline $\begin{array}{l}\text { *Correspondence: } \\
\text { iosdeby@yahoo.co.uk }\end{array}$ & $\begin{array}{l}\text { analyze the underlying variables of the study. The results revealed that there is a positive } \\
\text { interrelationship between online shopping and trust in Nigerian. The study concludes that online } \\
\text { service providers need to entrench trust amongst customers and exclude all risk factors that } \\
\text { could be inimical to the growth and development of online hopping in Nigeria. }\end{array}$ \\
\hline
\end{tabular}

CCIKD Publishing

In recent times, virtual engineering application permeates all phases of human endeavor (public private and corporate sector). In Nigeria, the traditional shopping experience has always been the only means for product sales and purchase exchanges until the early 1980s. The introduction of Information and Communications Technology (ICT) brought about a paradigm shift in the trio of seller-buyer-intermediaries relationship. This change was not without an increased volume of marketing literature on its impact in the process of initiating, establishing, and maintaining diverse facets of businesses ranging from; Customer to Customer $\mathrm{C} 2 \mathrm{C}$, Customer to Business $\mathrm{C} 2 \mathrm{~B}$, 
Business to Customer B2C, and Business to Business B2B relationships (Doney \& Joseph, 1997; Palmatier et al., 2007c).

Unlike conventional shopping, online shopping involves product sales and purchase through an intermediary to a wide range of customers worldwide. The Internet and other ICT peripherals facilitate this transaction. Online shopping has created an upward trend globally in merchandizing volume and value due to speed, accuracy, logistics, and feedback processes. In accomplishing this feat, intermediary firms have invested heavily in an aggressive and consistent relationship marketing approach. They aim at efficient and aggressive management of prospects and existing customers by sensitizing, attracting, and availing them with a product offering that meets the needs and wants of customers optimally; and at a minimal cost while creating a formidable feedback process that could address and resolve customers grievances (Robert, 2008). In avoiding the pitfall of mass marketing, online shopping involves collecting a mass volume of data about customers to pattern product offerings to suit the individualized need and want profitably.

Meanwhile, customers' trust is a crucial factor in the virtual platform based on end-user exposure to risk in any transaction at any given point in time. Lack of trust in the virtual platform has attracted so much inquisition by researchers. Various studies have shown that one of the prime causes of reduced patronage of online shopping is the time that takes the customer to build a relationship, trust, and confidence with an online intermediary since the myriads of fraudulent transactions experienced by customers lead to huge loss of investment capital on the virtual platform (Gefen, Karahanna, \& Straub, 2003). The role of trust in enhancing the unhindered relationship between virtual platform intermediaries and the customer cannot be overemphasized due to its importance in strategic growth and development of online shopping business (Sonja, 2002). The positive feature of uninhibited 'twenty-four hours per day, seven days per week' (24/7) access to customers has not been harnessed effectively by online intermediaries. Hence, all stakeholders need to craft a strategy that will reduce the envisaged risk faced by customers, by enhancing reliability, commitment, and customers' trust in the virtual platform.

However, the increased level of customer awareness and sophistication on what, where, why, and how of choice making on product/service offering has complicated the dilemma of online intermediaries. Extra effort and initiative are required to create captivating digital marketing content that will attract online traffic and elicit instant purchase decisions from customers and prospects (Raghunandan \& Parima, 2015; Sheth, Eshghi, \& Krishna, 2001). In essence, the positive role of ICT has sparked off the rage of a healthy competitive trend amongst online intermediaries globally, ensuring that comprehensive customer relationship marketing is deployed at every stage of the customers' experience while interacting with the virtual platform making a purchase decision. In reaction to this, online intermediaries are also emphasizing and sensitizing their customers and prospects on the availability of value-driven product services within a secured and convenient virtual environment.

As presented in Table 1, previous research has highlighted the importance of customers' trust in online shopping (Gefen, Karahanna, \& Straub, 2003; Jarvenpaa, Tractinsky, \& Vitale, 2000). They proposed that lack of customer trust is a tremendous strategic challenge to online shopping's growth and development. Other researches did a combination of risk and trust in online shopping experience in Nigeria (Olusoji, Ogunkoya, Lasisi, \& Elumah, 2015). The cultural dimension such as face consciousness and risk aversion affect online consumer decision making (Bao, Zhou, \& Su 2003). There has not been any study on customer predisposition to online shopping; hence the 
researcher saw the need to fill this literature gap in the Nigerian Online shopping business. This study is conceptualized on critically examining customers' preference for online shopping and trust in online shopping intermediaries.

Previous researchers have conceptualized customer trust in online shopping, as empirical evidence is listed in Table 1. The studies conducted by Flavián and Guinalíu (2006) and Jarvenpaa, Tractinsky, and Vitale (2000) focused on transaction security to guarantee customers' trust. An empirical research by Gefen, (2000) highlights the need for good customer relationship management in online shopping. In similar empirical research, Gefen (2002) conceptualized trust depending on loyalty and the service provider's capacity to deliver as promised. Gefen, Karahanna, and Straub (2003) also emphasized the need for trust as a tool for assessing the Total Available Market (TAM).

Other empirical studies by researchers such as Lee and Lee (2003) stressed the need for a trustworthy relationship between both parties to make an online transaction flourish. In a similar study, Lee and Lee (2005) focused on assessing perceived risk and anticipated benefits. Jarvenpaa and Tractinsky (1999) explained the need for cross-cultural consideration since online trading involves a global audience with diverse cultures. Also, Kirn, Xu, and Koh (2004) underlined trust as a key to customers' repeated purchases. Similarly, Koufaris, and Hampton-Sosa, (2004) stressed the need for trust in any engagements with the customer.

Table 1

Previous Conceptualization on Online Shopping and Customer Trust

\begin{tabular}{|c|c|c|c|}
\hline Study & Conceptualization & Item of Trust & Parameter of Measurement \\
\hline Flavián \& Guinalíu (2006) & $\begin{array}{l}\text { Perceived customer Loyalty } \\
\text { and customer Trust }\end{array}$ & E-commerce & Empirical Study; Privacy Policy \\
\hline Gefen (2000) & $\begin{array}{l}\text { Desire for quality Customer } \\
\text { Relationship Management }\end{array}$ & E-commerce & $\begin{array}{l}\text { Empirical Study; Customer } \\
\text { familiarity }\end{array}$ \\
\hline Gefen (2002) & $\begin{array}{l}\text { Perceived loyalty depends on } \\
\text { trust }\end{array}$ & E-commerce & $\begin{array}{l}\text { Empirical Study; Customer } \\
\text { Loyalty }\end{array}$ \\
\hline Gefen, Karahanna, \& Straub (2003) & $\begin{array}{l}\text { Desire to depend on service } \\
\text { provider }\end{array}$ & Online Trading & $\begin{array}{l}\text { Empirical Study; Customer Trust } \\
\text { and TAM }\end{array}$ \\
\hline Lee \& Lee (2003) & Perceived customer Trust & E-commerce & $\begin{array}{l}\text { Empirical Study; On Purchase } \\
\text { intention and customer Trust }\end{array}$ \\
\hline Lee \& Lee (2005) & Perceived customer intention & E-commerce & $\begin{array}{l}\text { Empirical Study; On Customer } \\
\text { Trustworthiness }\end{array}$ \\
\hline Li, Han, \& Kim $(2005$ & Effective trading standards & Online Shopping & $\begin{array}{l}\text { Empirical Study; utilizing set } \\
\text { conditions }\end{array}$ \\
\hline Jarvenpaa \& Tractinsky (1999) & $\begin{array}{l}\text { Ensuring that there is } \\
\text { integrity and trust }\end{array}$ & Online Trading & $\begin{array}{l}\text { Empirical Study; Integrity and } \\
\text { Customer Trust }\end{array}$ \\
\hline $\begin{array}{l}\text { Jarvenpaa, Tractinsky, \& Vitale, } \\
(2000)\end{array}$ & $\begin{array}{l}\text { Effective customer } \\
\text { relationship management }\end{array}$ & Online Trading & $\begin{array}{l}\text { Empirical Study; Integrity and } \\
\text { Customer Trust }\end{array}$ \\
\hline Kirn, Xu, \& Koh (2004) & $\begin{array}{l}\text { Effect of Customer Trust and } \\
\text { customer Retention }\end{array}$ & E-commerce & Empirical Study; Customer Trust \\
\hline Koufaris \& Hampton-Sosa (2004) & Perceived effect of trust & E-commerce & $\begin{array}{l}\text { Empirical Study; Integrity and } \\
\text { Customer Trust }\end{array}$ \\
\hline
\end{tabular}

\section{Problem of the Study}

The process of transmuting from conventional to online shopping lies in the ability of online shopping intermediaries to persuade and reassure existing customers and prospects of a formidable framework to guarantee the security of customers' investment and information whenever they execute any deal on the virtual platform. This has become a recurring decimal due to unauthorized persons' activities, such as hackers having unhindered access to customers' accounts. Online shoppers have without count lamented on the considerable amount of investments lost annually to 
these fraudsters, affecting their confidence. Such victims or prospects could repose on this valuable platform.

It is essential to express the need for online shopping intermediaries to provide a wide range of product assortment; ideally, customers will be ready to pay a premium for high-quality products at a minimal cost. It becomes absurd when a limited number of products are displayed online for customers to make their choices; this constrains customers to only making their choices based on availability and negates the liberty of choice-making, a common feature in the conventional shopping platform.

Similarly, another challenge faced by online shoppers is the issue of logistics of product delivery to customers after purchases. One of the primary features of the virtual platform is the convenience and speed of processing. Most online intermediaries are yet to perfect product delivery processes to customers, mostly in developing nations. Hence most orders made from remote regions of the country hardly get to the customers when due for delivery. There is an urgent need for online shopping intermediaries to embark on strategic logistic mapping of region, mostly remote areas, to improve product delivery.

Moreover, risk management and control issues refer to the extent to which online shoppers anticipate the possibility of not achieving their objectives or recovering their investment. The need arises for intermediaries to engage online shoppers through efficient and effective digital content marketing and the recovery that could guarantee customers of their investments' safety and establish a reliable customer feedback system that could resolve issues on the virtual platform.

\section{Objective of the Study}

The study's primary goal is to evaluate how Online Shopping customers could repose trust in virtual service intermediaries in Nigeria. The additional objectives are to identify the effect of risk control management of customers' accounts by online shopping intermediaries in Nigeria and to examine the need for effective logistics mapping of customers location by online shopping intermediaries in Nigeria

\section{Research Questions}

What is the effect of risk control management on customers' trust in the Nigerian online shopping service sector?

To what extent does logistics mapping of customer location affect trust in the Nigerian online shopping service sector?

\section{Research Hypotheses}

$\mathbf{H}_{1}$ : There is no relationship between risk control management and trust in the Nigerian online shopping service sector.

$\mathbf{H}_{2}$ : There is no interconnection between effective logistics mapping and trust in the Nigerian online shopping service sector.

\section{Conceptual Literature}

\section{Concept of Online Shopping;}

This concept is an electronically driven commercial transaction that allows end-users to interface with varieties of product services through the seller or an intermediary. Online shopping is often possible once the customer has direct access to the Internet. It enables the customer to browse 
product service owners' intermediaries and information such as product varieties, price, and delivery logistics. The development of Information and Communications Technology (ICT) has made online shopping one of the critical channels of service delivery with ease in the $21^{\text {st }}$ century and high consumer acceptability (Bourlakis, Papagiannidis, \& Fox, 2008). This platform's essential feature is the speed, convenience, and accessibility to varieties of product service guides (Butler \& Peppard, 1998; Yu \& Wu, 2007).

Online shopping requires customers to provide their personal information to enable the product service provider or its intermediary to build up a customer profile. Consequently, appropriate care must be taken by the online intermediary to guarantee the security, confidentiality, and privacy of the customers' detail (Bélanger et al., 2002). Hence, the need for product service providers and intermediaries to craft a privacy policy with their end-users (McGinity, 2000; Ranganathan \& Ganapathy, 2002). The repeated cases of unauthorized access to customers' account remain a significant challenge on the virtual platform; hence most end-users are scared of giving out their data for online shopping transactions (Brown \& Muchira 2004; Green, Yang, \& Judge, 1998; Hair, Anderson, Tatham, \& Black 1995). A study about the end-user's perspective on online shopping and end-user risk acknowledgment had the highest response (Vellido, Lisboa, \& Meehan, 2000). In another study on the safety of online financial transactions, the respondents assumed that their information with the service provider is secured, not transferable, and will not be accessible to fraudulent persons (Elliot \& Fowell, 2000; Flavián \& Guinalíu, 2006; Liao \& Cheung, 2001; Park \& Kim, 2003; Szymanski \& Hise, 2000).

\section{Concept of Trust}

The concept of trust is defined as the desire, eagerness, or inclination of an individual(s) to accept the outcome of another party's activity wholeheartedly without exerting any form of restrain in the process (Mayer, Davis, \& Schoorman, 1995). Similarly, Doney and Cannon (1997) posited that trust is preconceived acceptability and consideration of accomplishing a set objective. Mayer, Davis, and Schoorman (1995) were one of the earliest authors who studied trust related to online business transactions; the authors perceived that the key determinant of trust is the resolve to venture with the trustee's preconception dependable. Lee, Park, and Ahn (2001) highlighted two types of predetermined risks that could be encountered on the virtual shopping platform, such as losses incurred on investible capital, options, time, and product in the process of transacting online; the next risk includes safety, interference, and authenticity. In essence, the most outstanding combined risks are those incurred on investible capital, product-related risk, the safety of information, and interference (Bhatnager, Misra, \& Rao 2002)

The determining factors of online shopping trust include firms' image, market share, preconceived service delivery capacity, and industrial ranking. Organizational image is most often made better or worse by trending issues about the Internet's service provider. The market share of the firm in the industry can be a driving force that could enhance customer trust and confidence in the service provider (Grazioli \& Jarvenpaa, 2000; Jarvenpaa \& Tractinsky, 1999; Kirn, Xu, \& Koh, 2004; Koufaris \& Hampton-Sosa, 2004; Pavlou, 2003). Various researches have also affirmed that customers' preconceived opinion about the firms' ability to deliver quality service is also a significant determinant of trust and continued patronage (Anderson \& Fornell, 1994; Gefen, 2002; Grazioli \& Jarvenpaa, 2000; Kim \& Tadisina, 2007; Kirn, Xu, \& Koh, 2004; McKnight, Choudhury, \& Kacmar, 2002; Wakefield, Stocks, \& Wilder, 2004; Want \& Benbasat, 2005). 


\section{Theoretical Literature}

The theory of trust, according to Worchel (1979), has been redefined into three different categories as; i) Personality or Individualistic Trust theory, ii) Sociologists and Economists or Societal Trust Theory, and iii) Social Psychologists or Relationship Trust Theory. Based on this particular study, our concentration shall be on the Social Psychologists or relationship Trust Theory.

\section{Relationship Trust Theory}

This relationship trust theory is based on the expectation reposed by an individual or a group on other parties in the process of interaction. This theory's focal point is on the issues that enhance or destroy individual or group interaction (Duetsh 1958). Trust is also the desire to intensify that unguarded and total subservience to another party's actions that he/she does not have any form of authority over their resolves. According to Zand (1972), trust refers to a deliberate control of one's vulnerability based on the other parties decision to accomplish set objectives without recourse to the former. Hence, Zand clarified that the essence susceptibility in trust connotes that the desire to trust relies significantly on the party's ability to accomplish set objectives.

The desire to trust lies solely on the individual resolve that anticipates the desired result based on its significant value to the individual or group. Rempel, Holmes, and Zanna (1985) examined intimate interaction as it affects trust. They posited that trust is a universal impression on a person's expectation or a group on its possible future outcome. A similar study by Schlenker, Helm, and Tedeschi (1973) indicated that trust could depend on facts gathered from a person or a group regarding an unknown scenario in an undetermined circumstance.

\section{Trust in Human/Virtual Commercial Environment}

The process of applying trust in the electronic commercial environment involves the assumed interaction between humanity (animate) and Virtual Commercial Platform (Inanimate object). This will include creating a framework that will intermarry humanity and electronic commerce. To this end, there is a need for a critical study of the relationship between human behavior and trust on the electronic commercial platform. Research is also required to examine its willingness to interact with the virtual world in cognizance, the unsafe, unguarded, and total subservience needed for such a relationship to accomplish its goals and objective (Lohse \& Spiller, 1998).

\section{Empirical Literature}

In a study, Olusoji et al. (2015) investigated online shopping in line with perceived risk and trust between customers and intermediaries. They used primary sources through questionnaires in three locations: Lagos, Port Harcourt, and Abuja. The study findings showed a negative relationship between perceived risk and trust. Olusoji et al. recommended that the vast opportunities offered by online shopping to economic development should be harnessed.

Mao (2010) examined purchase intentions as the outcome of trust and evaluated trust's effect on risk aversion. They found a direct relationship between perceived quality service delivery by website and trust.

In a case study of the young generation in Pakistan, Muhammad, Muhammad, and Chaudhary (2015) examined consumer behavior on online shopping. The results of the study affirmed that there is a relationship between trust and online purchases. That trust was the main factor affecting the purchase behavior of the young generation.

In a similar study, Kooli, Ben Mansour, and Utama (2014) studied the determinant of online trust and its effect on online purchase intention. The objective of the study was a negative approach 
to online trust. The findings obtained from descriptive methodology revealed an interrelationship between purchase intention and online customer trust. The study concludes that a secured online platform will attract massive customer patronage

Santhi (2017) also examined the factors affecting online shopping decisions and their effects on customer satisfaction. The study used a descriptive methodology with questionnaires as a research instrument for data collection. The results revealed that there is a relationship between customers' satisfaction and online shopping. The study concluded that online customers should be enlightened on the steps needed in making an effective and successful online transaction.

\section{Methodology}

The descriptive survey technique was used and the data were collected through questionnaires with 7-point Likert scale. The researcher also conducted personal interviews with respondents to clarify areas not elaborately explained by the questionnaire on respondents' personal experience in online shopping. The study is based on online shopping and customer trust in Nigeria. Additional inputs include the effect of risk control management and the logistics mapping of customer location in online customers residents in Lagos (the commercial nerve center of Nigeria) and Abuja (Nigeria's administrative capital). The platform for customer interaction was a combination of a technologically-based electronic platform and a customer trust-based background. Professionals and experts examined the validity and reliability of the research instruments. A validity test was appropriately conducted on the research instrument by online shopping experts (engineers, technicians, and sales facilitators). Professionals and marketing scholars also affirmed the reliability of the questionnaires administered to respondents.

The customers were identified at patronizing jumia.com.ng, an online intermediary in Nigeria, and 277 questionnaires distributed to them. Of the total questionnaires administered, 237 (86\%) valid questionnaires were collected from the respondents; 14 respondents (5\%) did not send back the questionnaires, and 26 respondents $(9 \%)$ refused to respond. To ensure uniformity in the responses, a consistent approach was adopted to confirm respondents' answers systematically. Data collected were analyzed using Pearson Correlations Coefficient Technique. The null hypotheses were tested to affirm the relationship between the independent and dependent variables of the study.

\section{Reliability Analysis Test}

Cronbach's reliability alpha technique was used to examine the reliability of the constructs. The reliability was based on 21 variables with three constructs: reliability, tangibility, and service quality (Parasuraman, Zeithaml \& Berry, 1985; Parasuraman, Zeithaml, \& Berry, 1988; Parasuraman, Zeithaml, \& Berry, 1994). The total reliability coefficient for 237 respondents was .86 , which is reliable based on the benchmark that the Cronbach alpha value should be above.70 (Olayiwola, 2010; Speigel, 1992; Stevens, 1986).

\section{Hypothesis One}

The Pearson Correlations analysis outcome in Table 2 revealed a positive relationship between risk control management and trust whenever customers are shopping online, $r=.94, n=237, p<.0005$. The useable sample of the study was 237 . This result is in line with the results obtained by Lee and Lee (2005). Trust is guaranteed once business risks are mitigated or, if possible, eliminated (Gefen, Karahanna, \& Straub, 2003). 
Table 2

The Results of Correlation Analysis (Hypothesis One)

\begin{tabular}{llcc}
\hline & & Risk Control Management & Trust \\
\hline Risk Control Management & Pearson Correlation & 1.00 & .94 \\
& Sig. (2-tailed) & & .00 \\
\multirow{3}{*}{ Trust } & $\mathrm{N}$ & 237 & 237 \\
& Pearson Correlation & .94 & 1.00 \\
& Sig. (2-tailed) & .00 & 237 \\
\hline
\end{tabular}

** Correlation is significant at the 0.01 level (2-tailed).

\section{Hypothesis Two}

The Pearson Correlations analysis results in Table 3 revealed a positive interrelationship between effective logistic mapping and trust when customers are shopping on the online platform, $r=.87$, $n=237, p<.001$. The sample that was useful for the study was 237 . This result is in line with the results obtained by Li, Han, and Kim (2005) and Gefen, Karahanna, and Straub (2003). Trust involves an effective configuration of the back-office operations to synchronize effectively, which allows the customer to have unhindered access and trust in the online shopping platform (Jarvenpaa, Tractinsky, \& Vitale, 2000; Kirn, Xu, \& Koh, 2004; Koufaris \& Hampton-Sosa, 2004). This is a sure guarantee for customers to trust the platform to deliver as expected.

Table 3

The Results of Correlation Analysis (Hypothesis Two)

\begin{tabular}{llcc}
\hline & & Effective Logistic Mapping & Trust \\
\hline Effective Logistics Mapping & Pearson Correlation & 1.00 & .87 \\
& Sig. (2-tailed) & & .00 \\
\multirow{4}{*}{ Trust } & $\mathrm{N}$ & 237 & 237 \\
& Pearson Correlation & .87 & 1.00 \\
& Sig. (2-tailed) & .00 & 237 \\
\hline
\end{tabular}

\section{Conclusion}

Based on the discussion of findings, two items came to the fore; risk control management and effective logistic mapping of customer location as sine-qua-non to customer trust on the online shopping platform. Other factors such as firms' image, market share, preconceived service delivery capacity, and industrial ranking are vital to the growth and development of the online shopping platform. The increasing level of ICT growth has positioned the virtual platform as the only and best alternative to conventional shopping due to its speed of delivery, convenience, and flexibility. Hence stakeholders have to craft out strategies for establishing efficient online channels based on a dependable, secure, and risk-free online platform that could command customers' trust and unreserved confidence.

Marketing strategists should be able to provide digital contents that could attract customers' attention and arouse their interest to make orders on the e-commerce platform. This could be made possible if effective feedback processes can handle customers' complaints and provide effective solutions to such complaints. Also, the service providers should ensure that customers are satisfied. This could be made possible by providing quality products that could assuage the customers to orders and become ambassadors to the firm through word-of-mouth advertising. Hence online 
shopping could effectively thrive in Nigeria if trust is embedded as a tool to attract and retain customers.

\section{Reference}

Anderson, E. W., \& Fornell, C. (1994). A customer satisfaction research prospectus. In R. T. Rust, \& R. L. Oliver (Eds.), Service quality: New directions in theory and practice. Thousand Oaks, CA: Sage Publication.

Bao, Y., Zhou, K. Z., \& Su, C. (2003). Face consciousness and risk aversion: Do they affect consumer decision making? Wiley Periodicals, Inc. Published online in Wiley Inter-Science. https://doi.org/10.1002/mar.10094

Bélanger, F., Janine, H., \& Wanda, S. (2002). Trustworthiness in electronic commerce: The role of privacy, security, and site attributes. Journal of Strategic Information Systems 11, 245-270.

Bhatnager, A., Misra, S., \& Rao, H. R. (2000). On risk, convenience, and internet shopping behavior. Communications of the ACM , 43(11), 98-105.

Bourlakis, M., Papagiannidis, S., \& Fox, H. (2008). E-consumer behaviour: Past, present and future trajectories of an evolving retail revolution. International Journal of E-Business Research, 4(3), 64-76.

Brown, M., \& Muchira, R. (2004). Investigating the relationship between internet privacy concerns and online purchase behavior. Journal of Electronic Commerce Research, 5(1), 62-70.

Butler, P., \& Peppard, J. (1998). Consumer purchasing on the internet: Processes and prospects. European Management Journal, 16(5), 600-610.

Doney, P. M., \& Joseph P. C. (1997). An examination of the nature of trust in buyer seller relationships. Journal of Marketing, 61(4), 35-51.

Duetsh, M. (1958). Trust and suspicion. Journal of Conflict Resolution, 2(4), 265-279.

Elliot, S., \& Fowell, S. (2000). Expectations versus reality: A snapshot of consumer experiencesb with Internet retailing. International Journal of Information Management, 20(5), 323-336.

Flavián, C., \& Guinalíu, M. (2006). Consumer trust, perceived security and privacy policy: Tree basic elements of loyalty to a web site. Industrial Management and Data Systems, 106(5), 601-620.

Grazioli, S., \& Jarvenpaa, S. (2000). Perils of Internet fraud: An empirical investigation of deception and trust with experienced internet consumers. IEEE Transactions on Systems, Man, and Cybernetics, 30, 395-410.

Gefen, D. (2000). E-commerce: The role of familiarity and trust. Omega, 28(6), 725-737.

Gefen, D. (2002). Customer loyalty in e-commerce. Journal of the Association for Information Systems, 3, $27-51$.

Gefen, D., Karahanna, E., \& Straub, D. W. (2003). Trust and TAM in online shopping: An integrated model. MIS Quarterly, 27(1), 51-90.

Green, H., Yang, C., \& Judge, P. C. (1998). A little privacy, please. Business Week, 3569, 98-99.

Hair Jr, J. F., Anderson, R. E., Tatham, R. L., \& Black, W. C. (1995). Multivariate data analysis: With readings. Prentice Hall Upper Saddle River.

Jarvenpaa, S. L. \& Tractinsky, N. (1999). Consumer Trust in an Internet Store: A Cross-cultural Validation. Journal of Computer Mediated Communication 5(2), 1-35.

Jarvenpaa, S. L., Tractinsky, N., \& Vitale, M. (2000). Consumer trust in an Internet store. Information Technology and Management, 1, 45-71.

Kim, E., \& Tadisina, S. (2007). A model of customers' trust in e-businesses: micro-level inter-party trust formation. Journal of Computer Information Systems, 48(1), 88-104.

Kirn, H., Xu, Y., \& Koh, J. (2004). A comparison of online trust building factors between potential customers and repeat customers. Journal of Association for Information Systems, 5(10), $392-420$.

Kooli, K., Ben Mansour, K., \& Utama, R. (2014). Determinants of online trust and their impact on online purchase intention. International Journal of Technology Marketing, 9(3), 305-319.

Koufaris, M., \& Hampton-Sosa, W. (2004). The development of initial trust in an online company by new customers. Information and Management, 41(3), 377-397. 
Lee, D., Park, J., \& Ahn, J. (2001). On the explanation of factors affecting e-commerce adoption. Proceedings of the 22nd International Conference on Information Systems, 6, 109-120.

Lee, Y. K., \& Lee, K. Y. (2003). The effect of perceived trustworthiness on consumer trust in internet store. Korean Industrial Economic Association, 16(3), 127-140.

Lee, T. M., \& Lee, E. Y. (2005). A study on the determinants of purchase intention in mobile commerce: Focused on the mediating role of perceived risks and perceived benefits. Journal of MIS Research, 15(2), 1-21.

Li, M. Z., Han, K. S., \& Kim, G. Y. (2005). An empirical study on the utilizing conditions of online shopping mall of chinese consumers - focused on Beijing and Shanghai. Internet Business Research, 6(2), 55-78.

Liao, Z., \& Cheung, M. T. (2001). Internet-based e-shopping and consumer attitudes: An empirical study. Information and Management, 38(5), 299-306.

Lohse, G. L., Spiller, P. (1998). Electronic shopping. Communications of the ACM, 41(7), 81-87.

Mao, D. (2010). A study of consumer trust in internet shopping and the moderating effect of risk aversion in Mainland China (Unpublished bachelor's thesis). Hong Kong Baptist University.

Mayer, R. C., Davis, J. H., \& Schoorman, F. D. (1995). An integralive model of organizational trust. Academy of Management Review, 20(3), 709-734.

McGinity, M. (2000). Surfing your turf. Communications of the ACM, 43(4) 19-21.

McKnight, D. K., Choudhury, V., \& Kacmar, C. (2002). Developing and validating trust measures $\quad$ for $\quad$ e-commerce: An integrative typology. Information Systems Research, 13(3), 334-359.

Muhammad, K. B., Muhammad, I., \& Chaudhary, A. R. (2015). Online shopping trend and its effects in consumer buying behavior: A case study of young generation of Pakistan. NG-Journal of Social Development, 5(1). Retrieved from www.arabianjbmr.com/NGJSD_index.php

Olayiwola, A. O. (2010). Procedures in educational research Nigeria. Hanjam Publications. Retrieved from http:/www..hrdc.drhc.gc.ca/arb/

Olusoji, J. G., Ogunkoya, O. A., Lasisi, J. O., \& Elumah, L. O. (2015). Risk and trust in online $\quad$ shopping: Experience from Nigeria. International Journal of African and Asian Studies. Retrieved from www.iiste.org

Palmatier, R. W., Lisa, K., Scheer, M., B., Houston, K., Evans, R., \& Srinath, G. (2007c). Use of relationship marketing programs in building customer-salesperson and customer-firm relationships: Differential influences on financial outcomes. International Journal of Research in Marketing, 24(9), 210-23.

Parasuraman, A., Zeithaml, V. A., \& Berry, L. L. (1985). A conceptual model of service quality and its implications for future research, Journal of Marketing, 49(3), 41-50.

Parasuraman, A., Zeithaml,V. A., \& Berry, L. L. (1988). SERVQUAL: A multi- item scale for measuring consumer perceptions of service quality. Journal of Retailing, 64(1), 13-40.

Parasuraman, A., Zeithaml, V., \& Berry, L. L. (1994). Reassessment of expectations as a comparison standard in measuring service quality: Implications for further research. Journal of Marketing, 5(1), 111-124.

Park, C. H., \& Kim, Y. G. (2003). Identifying key factors affecting consumer purchase behavior in an online shopping context. International Journal of Retail and Distribution Management, 31(1), 16-29.

Pavlou, P. A. (2003). Consumer acceptance of electronic commerce: integrating trust and risk with the technology acceptance model. International Journal of Electronic Commerce, 7(3), 101-134.

Raghunandan, H., \& Parimal, N. (2015). Integrated digital marketing: The key to understanding your customers. Tata Consultancy Service White Paper.

Ranganathan, C., \& Ganapathy, S. (2002). Key dimensions of business-to-consumer web sites. Information and Management, 39(6), 457-465.

Rempel, J. K., Holmes, J. G., \& Zanna, M. P (1985). Trust in close relationships. Journal of Personality and Social Psychology, $49,95-112$.

Robert, W. P. (2008). Relationship marketing. Massachusetts Ave., Cambridge: Marketing Science Institute.

Santhi, A. B. (2017). A study on the customer satisfaction towards online shopping in Tirupati Town. Journal of Business and Management, 19, 12-16.

Schlenker, B. R., Helm, B., \& Tedeschi, J. T. (1973). The effects of personality and situational variables on behavioral trust. Journal of Personality and Social Psychology, 25(3), 419-427.

Sheth, J. N., Eshghi, A., \& Krishna, B. C. (2001). Internet marketing. Fort Worth: Harcourt College Publishers.

Sonja, G. (2002). The role of consumers' trust in online-shopping. Journal of Business Ethics, 39(1/2), 43-51.

Speigel, M. (1992). Synthesizing evaluation perspectives, practices and evidences. Proceedings of the American Evaluation Association. 92 Extension Evaluation Topical interest group, 27-37, Seattle WA. 
Stevens, J. (1986). Applied multivariate statistics for the social sciences. Hillsdale: NJ Eribaun.

Szymanski, D. M., \& Hise, R. T. (2000). E-satisfaction: An initial examination. Journal of Retailing, 76(3), 309-322.

Vellido, A., Lisboa, P. J. G., \& Meehan, K. (2000). Quantitative characterization and prediction of online purchasing behavior: A latent variable approach. International Journal of Electronic Commerce, 4(4), 83-104.

Wakefield, R. L., Stocks, M. H., \& Wilder, W. M. (2004). The role of web site characteristics in initial trust formation. Journal of Computer Information Systems, 45(1), 94-103.

Worchel, P. (1979). Trust and distrust. In W.G. Austin, \& S. Worchel (Eds.), The social psychology of intergroup relations (pp. 27-54). Belmont, CA: Wadsworth.

Yu, T., \& Wu, G. (2007). Determinants of internet shopping behavior: An application of reasoned behavior theory. International Journal of Management, 24(4), 744-762.

Zand, D. E. (1972). Trust and managerial problem solving. Administrative Science Quarterly, 17, 229-239. 